\title{
UNDERNUTRITION PREVALENCE AMONG CHILDREN UNDER TWO YEARS OLD IN INDONESIA DURING ECONOMIC CRISIS AND ITS RELATED FACTORS
}

\author{
(Prevalensi Kurang Gizi pada Anak Bawah Dua Tahun di Indonesia pada Masa Krisis Ekonomi dan \\ Faktor-Faktor yang Berhubungan) \\ Anna Vipta Resti Mauludyani", Umi Fahmida ${ }^{1}$, dan Otte Santika ${ }^{1}$ \\ ${ }^{1}$ South East Asian Ministries of Education Organization, Regional Center for Food and Nutrition (SEAMEO \\ RECFON), University of Indonesia
}

\begin{abstract}
The objective of this study was to assess undernutrition prevalence among children under-two years in Indonesia and its related factors. This ecological study was conducted to 437 districts using data extracted from nationally representative surveys, which were National Socioeconomic Survey (Susenas) and National Basic Health Research (Riskesdas) year 2007. Overall, prevalence of High Stunting (HS), High Wasting (HW), and High Underweight (HU) was 46.9\%, 59.5\%, and 17.2\%, respectively. Median prevalence of inadequate intake of energy, protein, iron, and zinc were $33.3 \%, 11.1 \%, 81.8 \%$, and $55.6 \%$, respectively. Median prevalence of Acute Respiratory Infection (ARI) was $15.9 \%$, while the median prevalence of diarrhea was $13.0 \%$. Median proportion of low education of the mother was 46.9\%. Prevalence of HS was associated with household income, low education proportion of mother, and proportion of food expenditure. Prevalence of HW was associated with prevalence of inadequate energy intake and proportion of food expenditure. Prevalence of $\mathrm{HU}$ was associated with proportion of low education of mother and proportion of food expenditure.
\end{abstract}

Keywords: children under-two years, economic crisis, undernutrition

\section{ABSTRAK}

Studi ini bertujuan untuk mengetahui prevalensi kurang gizi pada anak bawah dua tahun (baduta) dan faktorfaktor yang berhubungan. Studi ekologi ini dilakukan pada 437 kabupaten/kota menggunakan data yang mewakili nasional, yaitu Survei Sosial Ekonomi Nasional (Susenas) dan Riset Kesehatan Dasar (Riskesdas) tahun 2007. Secara umum, prevalensi High Stunting (HS), High Wasting (HW), dan High Underweight (HU) secara berturut-turut adalah $46.9 \%$, 59.5\%, dan $17.2 \%$. Median prevalensi ketidakcukupan asupan energi, protein, zat besi, dan seng berturut-turut adalah $33.3 \%, 11.1 \%, 81.8 \%$, dan $55.6 \%$. Median prevalensi ISPA adalah $15.9 \%$, sedangkan untuk diare adalah $13.0 \%$. Median persentase ibu dengan pendidikan rendah adalah $46.9 \%$. Prevalensi HS berhubungan dengan pendapatan rumah tangga, persentase ibu dengan pendidikan rendah, dan pangsa pengeluaran pangan. Prevalensi HW berhubungan dengan prevalensi ketidakcukupan energi dan pangsa pengeluaran pangan. Prevalensi HU berhubungan dengan persentase ibu dengan pendidikan rendah dan pangsa pengeluaran pangan.

Kata kunci: anak baduta, krisis ekonomi, kurang gizi

"Korespondensi: Departemen Gizi Masyarakat, Fakultas Ekologi Manusia (FEMA), Institut Pertanian Bogor, Jl. Raya Darmaga, Bogor 16880; Email: vipta11@yahoo.com 


\section{INTRODUCTION}

Global economic crisis as the combination of food, fuel, and financial crisis in 2007-2008 caused increase in global food price. The agricultural production potential (more land and irrigation, higher yields) which were failed to develop with the growing needs made biofuel feedstock prices (in relation to the price of petroleum) arose to uneconomic energy production level (Tyner et al. 2007). The three commodities including all non fuel, metals and oil continued to undergo price increase (Radetski 2006). In term of consumption, this food crisis and high food price was caused by increased food demand as the impact of rapid population growth and high economic growth, especially in China and India (Alexandratos 2008). The rate of price index of wheat, corn, and rice was increased from $16.7 \%$ in 2006 became 50.6\% in 2008 (Rusastra et al. 2010). Moreover, according to Brinkman et al. (2010), between 2000 and its peak in 2008, the FAO cereal price index was more than tripled.

The food price increase can have direct effect on food security or on insufficient utilization, availability, and accessibility to adequate and safe diets (Darnton-Hill et al. 2010). The study results from Ahmed et al. (2010) showed that the crisis caused increased in poverty at macro level by 80 percent, from 22 to 40 percent, while in micro level, there was 4 percent increase in poverty and 1.3 percent reduced food consumption.

Households have reduced the quantity and quality of food consumed in the face of higher food price. The reduction was seen in the consumption of high-quality foods (Block et al. 2004). Households reduce energy intake in response to increased food price and reduced income. The pathway is by reducing the size and frequency of meals in their consumption. When household reduce the size and number of meals, they will likely suffer deficiencies in macronutrient, including energy and protein (Brinkman et al. 2010).

Inadequate food intake makes the impact of price increase is worse in children as one of vulnerable groups since malnutrition in child is associated with inadequate food intake (Block et al. 2004). During this period, they pose a significant threat to children's survival, growth and development, which affects children's ability to learn in school, and to work and prosper as adults (UNICEF 2009). In other word, short term consequences of malnutrition are morbidity, mortality, and disability, while long term consequences are adult size, intellectual ability, economic productivity, reproductive performance, metabolic and cardiovascular disease (Black et al. 2008).

The National Socio-Economic Survey (Susenas) and Basic Health Research (Riskesdas) data are potential data sources to analyze food and nutrition. Susenas is annual household survey made to collect socioeconomic data widely in national scope conducted by Central Bureau of Statictics (BPS), while Riskesdas in conducted by National Institute of Health Research and Development, $\mathrm{MOH}$, to collect data regarding health and nutrition ( $\mathrm{MOH} 2008)$. Both surveys involve large numbers of samples with national scope, include hundreds of variables, have good methodology, and use billions of budgets. Therefore, using Susenas and Riskesdas data are optimizing available and accessible resources.

Study on undernutrition prevalence among children under-two years using national data is still limited, especially in Indonesia. Therefore, this study is important to be conducted.

\section{METHODS}

\section{Design, Place, and Time}

This ecological study was conducted from February to July 2011. The data used in this analysis were collected from nationally representative surveys, which were National Socioeconomic Survey (Susenas) and National Basic Health Research (Riskesdas) year 2007.

Susenas is household survey made to collect socioeconomic data widely in national scope. The sampling of Susenas was multistage cluster sampling. It is charged with a mission to gather socio-economic data among others, concerning education, demography, health/nutrition, housing/environment, criminality, socio-culture activities, household consumption/expenditure, domestic travel, and community opinion regarding their own welfare. The data collection is conducted in February-March 2007. The Susenas collects data on two groups of consumption, i.e. food and non-food consumption. There are 215 items of household food consumption appeared in the questionnaire in terms of quantities and values. For non-food consumption items, which consists of 104 items, only data on value is collected, except for some consumption items such as electricity, water, fuel, and charcoal. The interview is conducted to head of household or other household member who is familiar with the household's affairs. Total household in Core Susenas 2007 was 274 184. Number of household included in Module Susenas 2007 was 64880 . This study analyzed 14767 households having children less than two years included in Susenas 2007. The households came from 437 districts in 33 provinces in Indonesia.

Riskesdas 2007 is a descriptive cross sectional survey carried by National Institute of Health Research and Development, $\mathrm{MOH}$. The subject of household and household member in Riskesdas 2007 was designed identically with the list of household and household sample in Susenas 2007. The data 
collection was started from July 2007-September 2008. To obtain data on individual intake of children under-two, Riskesdas conducted single 24-hour recall through interview with head of household or housewives who can give information. Riskesdas 2007 collected information from 258366 household sampled.

\section{Total Subject and Sampling Procedure}

Total number of children under two years in Riskesdas was 31569 children from 440 districts in 33 provinces in Indonesia. Since the data was in unit of analysis of district, 3 districts from Riskesdas were taken out to match the Susenas. The z-score was compared to WHO standard for exclusion criteria (HAZ -6 and +6 , WHZ -5 and +5 , WAZ -6 and $+5)$. Finally, 25922 children from 437 districts were taken as the subject.

Unit of analysis used in this study was districts. The justification of using district as subject unit was the spatial heterogeneity in socio-economic parameters: poor people tend to be clustered in specific places (MOA et al. 2005). Therefore, analysis on district level was useful to capture the variation which further used as determination in formulating effective policy by decision makers. Subject in this study was 437 districts.

\section{Data Processing and Analysis}

All data have been collated from 2 secondary sources of the Central Bureau of Statistics (BPS) and $\mathrm{MOH}$, which were Susenas and Riskesdas year 2007, respectively. Total monthly $\mathrm{HH}$, food, and strategic food expenditure in $\mathrm{Rp} / \mathrm{cap} / \mathrm{mo}$ were obtained from Susenas, while Riskedas provide data on weight, height, birth weight, intake of energy, protein, iron, and zinc, occurrence of Acute Respiratory Infection (ARI) and diarrhea, and mother's education. Stunting, wasting, and underweight was determined by using cutoff $<2$ SD Z-scores. High stunting was prevalence of $30 \%$ upper. High wasting was obtained by cut off of $15 \%$ upper, while high underweight was categorized by cut off of 20\% upper (WHO 2010).

Data on birth weight of children in gram was transformed into prevalence of Low Birth Weight (LBW) (<2 $500 \mathrm{~g})$ per district. When data on birth weight was not available for particular district, provincial data where the respective district existed was used. Nutrient intake of children under-two was compared to nutrient requirements from complementary foods with average breastmilk intake in developing countries obtained from Dewey et al. (2003). A particular nutrient intake was considered adequate if the percentage to $\mathrm{RDA} \geq 77 \%$. Data on individuals was then transformed into prevalence of inadequacy for each nutrient per district.

Data on health status was obtained from prevalence of ARI and diarrhea per district. The data was analyzed in continuous form. Mother's education was considered low based on elementary school (graduated) and less. When data on mother's education in particular district was not available, provincial data where the respective district existed was used.

Total household expenditure was used as proxy for income. Further, income was categorized as low (40\% lowest income), medium (40\% higher income), and high (20\% highest income). Proportion of food expenditure in percentage was obtained by dividing food expenditure by total $\mathrm{HH}$ expenditure, both in Rp/cap/mo. Proportion of food expenditure was used also to determine household food security with $>60 \%$ was considered as food insecure. In each household, expenditures on different food items, including rice, corn, cassava, sweet potatoes, wheat flour, soybean, beef, egg, chicken, milk, fish, sugar, cooking oil, formula milk, and manufactured complementary food (manufactured CF) in the previous week was collected. Expenditure on food was grouped into 7 categories: 1) rice; 2) non-rice staple, the sum of expenditures on corn, cassava, sweet potatoes, and wheat flour; 3) plant protein; 4) animal protein, the sum of expenditures on beef, egg, chicken, milk, and fish; 5) sugar and cooking oil; 6) formula milk; and 7) manufactured CF.

Chi-square tests and bivariate logistic regression were used to examine the relationship between nutritional status and its various underlying indicators. Separate multivariate logistic regression models were performed to examine relationship between food expenditure categories and high stunting, high wasting, and high underweight prevalence. Variables that are significantly associated with high stunting, high wasting, and high underweight prevalence in the previous test were included in the final multivariate models. P-value $<0.05$ was considered significant. Data analyses were conducted using SPSS version 16.

This study was conducted after receiving permission from Indonesian Center for Agriculture Socio Economic and Policy Studies (ICASEPS), MOA, to use Susenas data year 2007. Permission from $\mathrm{Na}$ tional Institute of Health Research and Development (NIHRD), MOH, was also obtained to use Riskesdas data year 2007.

\section{RESULTS AND DISCUSSION}

Overall, prevalence of high stunting, high wasting, and high underweight was $46.9 \%, 59.5 \%$, and $17.2 \%$, respectively. This showed that malnuttrition problem is still prevalent in Indonesia. Median prevalence of inadequate intake of energy, protein, iron, and zinc among children under-two were $33.3 \%, 11.1 \%, 81.8 \%$, and $55.6 \%$, respectively. Prevalence of energy, iron, and zinc were ranged 
between 0 to $100 \%$, while it was ranged from 0 to $75 \%$ for protein. There was significant association of household income with prevalence of inadequate iron and zinc intake. Higher household income was associated with lower prevalence of inadequate iron and zinc intake. With high income, household is capable to find more micronutrient-rich-food, such as animal and plant protein, fruit and vegetable.

Overall, median prevalence of ARI among children under-two was $15.9 \%$, ranged from 0 to $71.4 \%$. Median prevalence of diarrhea was $13.0 \%$ with range between 0 and $50 \%$. Higher household income was significantly associated with lower diarrhea prevalence. Higher income gave opportunity to provide high quality of nutrient source. Micronutrients, such as iron and zinc, are responsible to prevent child from diarrhea.

Median low education proportion of the mother was $46.9 \%$, ranged from $6.1 \%$ to $100 \%$. This study found no association between income class and low education proportion of the mother. Higher income does not always give opportunity to the mother to have higher education, since the income is used mainly to fulfill need for food.

Prevalence of LBW was not associated with prevalence of high stunting, wasting, and underweight of children under-two (Table 1), while there was significant association between prevalence of inadequate energy intake and prevalence of high wasting among children under-two (Table 2).
Bivariate analysis found no association of prevalence of ARI in the last one month with prevalence of high stunting, wasting, and underweight among children under-two. Similar with ARI, there was no association of prevalence of diarrhea in the last one month with prevalence of high stunting, wasting, and underweight among children undertwo (Table 3). Wasting indicates current malnutrition. Therefore, the result of this study showed that the malnutrition was caused more by inadequate food intake which happen in recent time rather than the disease (Babatunde et al. 2011).

Bivariate analysis showed that household income was associated with prevalence of high stunting among children under-two (Table 4). District with low income were at higher risk of having high stunting. Stunting is an indicator of past growth failure. Therefore, this study showed that the crisis, which happened for quite long time, caused reduction of real income which was responsible for inadequate intake as the cause of stunting (Olivieri et al. 2007).

Low education proportion of the mother was associated with risk of having high prevalence of high stunting and high underweight (Table 4). This was in line with Torlesse et al. (2003), Campbell et al. (2010), and Sari et al. (2010) which stated that lower maternal education was associated with higher risk of stunting and underweight. Mother with low education tends to have limited knowledge on

Table 1. Association of LBW Prevalence with Undernutrition Prevalence among Children 0-23 Month Old

\begin{tabular}{cccccccccc}
\hline \multirow{2}{*}{ Variables } & \multicolumn{3}{c}{ HS $(\mathrm{n}=205)$} & \multicolumn{3}{c}{ HW $(\mathrm{n}=260)$} & \multicolumn{3}{c}{ HU $(\mathrm{n}=70)$} \\
\cline { 2 - 25 } & \% HS & OR & p-value & $\%$ HS & OR & p-value & $\%$ HS & OR & p-value \\
\hline LBW prevalence & 46.9 & 0.834 & 0.277 & 59.5 & 1.226 & 0.268 & 17.2 & 0.953 & 0.825 \\
\hline
\end{tabular}

Table 2. Association of Nutrient Inadequacy Prevalence with Undernutrition Prevalence among Children 0-23 Month Old

\begin{tabular}{cccccccccc}
\hline \multirow{2}{*}{ Variables } & \multicolumn{3}{c}{ HS $(\mathrm{n}=205)$} & \multicolumn{3}{c}{ HW $(\mathrm{n}=260)$} & \multicolumn{3}{c}{ HU $(\mathrm{n}=70)$} \\
\cline { 2 - 9 } & \% HS & OR & p-value & $\%$ HS & OR & p-value & $\%$ HS & OR & p-value \\
\hline Energy* & 46.9 & 0.997 & 0.612 & 59.5 & 0.984 & $0.006^{* *}$ & 17.2 & 0.994 & 0.466 \\
Protein* & & 1.004 & 0.641 & & 0.990 & 0.232 & & 1.007 & 0.539 \\
Iron* & & 1.006 & 0.284 & & 1.003 & 0.655 & 1.013 & 0.144 \\
Zinc* & & 0.998 & 0.676 & & 0.992 & 0.067 & 0.997 & 0.637 \\
\hline
\end{tabular}

Table 3. Association of Disease Prevalence with Undernutrition Prevalence among Children 0-23 Month Old

\begin{tabular}{cccccccccc}
\hline \multirow{2}{*}{ Variables } & \multicolumn{3}{c}{ HS $(\mathrm{n}=205)$} & \multicolumn{3}{c}{ HW $(\mathrm{n}=260)$} & \multicolumn{3}{c}{ HU $(\mathrm{n}=70)$} \\
\cline { 2 - 9 } & \% HS & OR & p-value & $\%$ HS & OR & p-value & $\%$ HS & OR & p-value \\
\hline ARI & 46.9 & 0.998 & 0.781 & 59.5 & 0.985 & 0.060 & 17.2 & 0.985 & 0.189 \\
Diarrhea $^{* * *}$ & & 1.008 & 0.455 & & 1.008 & 0.515 & & 1.020 & 0.169 \\
\hline
\end{tabular}

* Energy, protein, iron and zinc were in term of inadequate intake prevalence

** Logistic regression, $\mathrm{p}<0.05$

*** ARI and diarrhea were in term of prevalence in the last 1 month

HS: High Stunting; HW: High Wasting; HU: High Underweight 
Table 4. Association of Household Income and Low Education Proportion of the Mother with Undernutrition Prevalence among Children 0-23 Month Old

\begin{tabular}{|c|c|c|c|c|c|c|c|c|c|}
\hline \multirow{2}{*}{ Variables } & \multicolumn{3}{|c|}{ HS $(n=205)$} & \multicolumn{3}{|c|}{$H W(n=260)$} & \multicolumn{3}{|c|}{$\mathrm{HU}(n=70)$} \\
\hline & $\% \mathrm{HS}$ & OR & $\mathrm{p}$-value & $\% \mathrm{HS}$ & OR & $\mathrm{p}$-value & $\% \mathrm{HS}$ & OR & $\mathrm{p}$-value \\
\hline \multicolumn{10}{|l|}{ Income: } \\
\hline Low* & 50.9 & 1.00 & - & 59.4 & 1.00 & - & 16.6 & 1.00 & - \\
\hline Medium & 48.0 & 0.892 & 0.593 & 58.9 & 0.977 & 0.913 & 21.7 & 1.370 & 0.264 \\
\hline High & 36.8 & 0.562 & $0.032^{* *}$ & 60.9 & 1.064 & 0.817 & 9.2 & 0.555 & 0.167 \\
\hline $\begin{array}{l}\text { Low education of the } \\
\text { mother }\end{array}$ & & 1.021 & $<0.001^{* *}$ & & 1.005 & 0.336 & & 1.029 & $<0.001^{* *}$ \\
\hline
\end{tabular}

Table 5. Association of Household Food Expenditure with Undernutrition Prevalence among Children 0-23 Month Old

\begin{tabular}{lccccccccc}
\hline \multirow{2}{*}{ Variables } & \multicolumn{3}{c}{ HS $(\mathrm{n}=205)$} & \multicolumn{3}{c}{$\mathrm{HW}(\mathrm{n}=\mathbf{2 6 0})$} & \multicolumn{3}{c}{$\mathrm{HU}(\mathrm{n}=\mathbf{7 0})$} \\
\cline { 2 - 10 } & \% HS & OR & $\mathrm{p}$-value & \% HS & OR & p-value & $\%$ HS & OR & p-value \\
\hline $\begin{array}{l}\text { Proportion of food } \\
\text { expenditure: }\end{array}$ & & & & & & & & & \\
$\quad$ Tertile 1*** & 37.1 & 1.00 & - & 46.4 & 1.00 & - & 8.6 & 1.00 & - \\
$\quad$ Tertile 2 & 50.7 & 1.739 & $0.022^{* *}$ & 62.3 & 1.909 & $0.007^{* *}$ & 17.8 & 2.311 & $0.024^{* *}$ \\
$\quad$ Tertile 3 & 52.4 & 1.864 & $0.010^{* *}$ & 69.0 & 2.564 & $<0.001^{* *}$ & 21.4 & 2.901 & $0.003^{* *}$ \\
\hline
\end{tabular}

* Low income was the reference category

** Logistic regression, $\mathrm{p}<0.05$

*** Low proportion of food expenditure was the reference category

HS: High Stunting; HW: High Wasting; HU: High Underweight

health and nutrition which is important to practice good caring related to feeding and disease management.

There was significant association of proportion of household food expenditure with prevalence of high stunting, wasting, and underweight among children under-two (Table 5). Higher proportion of household food expenditure was associated with risk of having high prevalence of high stunting, high wasting, and high underweight. The households are food insecure, so that they may have problem in fulfilling the need for food (Melgar-Quinonez et al. 2006).

\section{CONCLUSIONS}

Overall, prevalence of high stunting, high wasting, and high underweight was $46.9 \%$, 59.5\%, and $17.2 \%$, respectively. Prevalence of high stunting was associated with income, proportion of low education of mother, and proportion of food expenditure. Prevalence of high wasting was associated with prevalence of inadequate energy intake and proportion of food expenditure. Prevalence of high underweight was associated with proportion of low education of mother and proportion of food expenditure. This study recommended that enhancing income generation and education are essential to reduce undernutrition prevalence.

\section{REFERENCES}

Ahmed V \& Donoghue CO. 2010. Global Economic Crisis and Poverty in Pakistan. International Journal of Microsimulation, 3(1), 127-12.

Alexandratos N. 2008. Pood Price Surges: Possible Causes, Past Experiences and Relevance for Exploring Long-Term Prospects. Population and Development Review, 34(4), 663-97.

Babatunde RO, Olagunju FI, Fakayode SB, \& SolaOjo FE. 2011. Prevalence and Determinants of Malnutrition among Under-five Children of Farming Households in Kwara State, Nigeria. Journal of Agricultural Science, 3(3), 17381.

Black RE, Allen LH, Bhutta ZA, Caulfield LE, de Onis M, Ezzati M, Mathers C, \& River J. 2008. Maternal and child undernutrition: Global and regional exposures and health consequences. Lancet, 371, 243-60.

Block SA, Kiess L, Webb P, Kosen S, Moench-Pfanner R, Bloem MW, \& Timmer CP. 2004. Macro shocks and micro outcomes: child nutrition during Indonesia's crisis. Economics \& Human Biology, 2(1), 21-44.

Brinkman H-J, de Pee S, Sanogo L, Subran L, \& Bloem MW. 2010. High food prices and the global financial crisis have reduced access to nutritious food and worsened nutritional status 
and health. The Journal of Nutrition, 140, 153-61.

Campbell AA, De Pee S, Sun K, Kraemer K, ThorneLyman A, Moench-Pfanner R, Sari M, Akhter N, Bloem MW, \& Semba RD. 2010. Household rice expenditure and maternal and child nutritional status in Bangladesh. The Journal of Nutrition, 140, 1895-94S.

Darnton-Hill I \& Cogill B. 2010. Maternal and young child nutrition adversely affected by external shocks such as increasing global food prices. The Journal of Nutrition, 140, 162-9.

Dewey KG \& Brown KH. 2003. Update on technical issues concerning complementary feeding of young children in developing countries and implications for intervention programs. Food and Nutrition Bulletin, 24, 5-28.

Melgar-Quinonez HR, Zubieta AC, MkNelly B, Nteziyaremye A, Gerardo MFD, \& Dunford C. 2006. The Journal of Nutrition, 136(5), 1431S14375 .

MOA \& WFP. 2005. A Food Insecurity Atlas of Indonesia. National Food Security Council, Ministry of Agriculture and World Food Programme.

$\mathrm{MOH}$. 2008. Report on result of National Basic Health Research (Riskesdas) 2007. The National Institute of Health Research and Development, Ministry of Health, Republic of Indonesia.

Olivieri F, Semproli S, Pettener D, \& Toselli S. 2007. Growth and Malnutrition of Rural Zimbabwean Children (6-17 Years of Age). American Journal of Physical Anthropology, 136(2), 214-222.
Radetski M. 2006. The Anatomy of Three Commodity Booms. Resources Policy, 31, 56-64.

Rusastra IW, Saliem HP, \& Ashari. 2010. Krisis Global Pangan-Energi-Finansial: Dampak dan Respon Kebijakan Ketahanan Pangan dan Pengentasan Kemiskinan. Jurnal Analisis Kebijakan Pertanian, 8(1), 29-48.

Sari M, De Pee S, Bloem MW, Sun K, Thorne-Lyman AL, Moench-Pfanner R, Akhter N, Kraemer K, \& Semba RD. 2010. Higher household expenditure on animal-source and nongrain foods lowers the risk of stunting among children 0-59 months old in Indonesia: implications of rising food prices. The Journal of Nutriion, 140, 195S-200S.

Torlesse H, Kiess L, \& Bloem MW. 2003. Association of household rice expenditure with child nutritional status indicates a role for macroeconomic food policy in combating malnutrition. The Journal of Nutrition, 133, 1320-5.

Tyner W \& Taheripour F. 2007. Renewable Energy Policy Alternatives for the Future. American Journal for Agricultural Economics, 89(5), 1303-10.

UNICEF. 2009. Tracking progress on child and maternal nutrition: A survival and development priority. United Nations Children's Fund, New York.

WHO. 2010. Nutrition Landscape Information System (NLIS) country profile indicators: interpretation guide. World Health Organization, Geneva. 